\title{
SENSITIVITY OF OPTION CONTRACTS
}

\author{
Raimonda Martinkute-Kauliene \\ Vilnius Gediminas Technical University, Sauletekio al. 11, LT-10223 Vilnius, Lithuania \\ E-mail: raimonda.martinkute@vgtu.lt
}

Received 14 Dec. 2012; accepted 31 Mar. 2013

\begin{abstract}
There are plenty of reasons why investors use option contracts in their portfolios. The main reason for using such contracts or their strategies is to hedge against risk concerned with the uncertainty of underlying asset price movements. The identification of risk factors and their management is essential for all kinds of business. However, the process of risk assessment and management is especially important in the case of using complex activities such as option contracts. Options have characteristics that may make them less attractive for some investors. Options can be risky but provide opportunities to profit for those who properly use this flexible instrument. Before the investor can explore the application of strategies for various options, first, he must be able to analyze and understand the degree of risk they impose. The purpose of the article is to analyze the basic measures of option risk, sensitivity factors and their meaning to the investor. When understanding, calculating and using such measures as delta, gamma, theta and vega, the investor can manage the riskiness of the option and the whole portfolio. Each Greek letter measures a different dimension of risk in an option position.
\end{abstract}

Keywords: call option, put option, price, value, time for expiration, strike price, the Greeks, volatility, risk, sensitivity, delta, gamma, theta.

JEL Classification: G10, G12.

\section{PASIRINKIMO SANDORIŲ JAUTRUMO VEIKSNIŲ TYRIMAS}

\author{
Raimonda Martinkutè-Kaulienè
}

Vilniaus Gedimino technikos universitetas, Sauletekio al. 11. LT-10223 Vilnius, Lietuva

El.paštas raimonda.martinkute@vgtu.lt

Iteikta 2012-12-14; priimta 2013-03-31

\begin{abstract}
Santrauka. Yra daugybė priežasčių, kodèl investuotojai naudoja pasirinkimo sandorius savo investiciniuose portfeliuose. Pagrindinè iš jų - apsidrausti nuo bazinio turto kainos neapibrèžtumo ir galimų pokyčių rinkoje. Rizikos veiksnių nustatymas ir valdymas yra svarbus bet kuriam verslui. Bet jis ypač svarbus naudojant mažiau žinomas, sudètingos struktūros finansines priemones, tokias kaip pasirinkimo sandoriai ir jų deriniai. Pasirinkimo sandoriai, be savo naudojimo privalumų, turi ir ne tokių patrauklių savybių, kurios kai kuriems investuotojams gali būti ir nepriimtinos. Pasirinkimo sandoriai gali būti rizikingi, bet tinkamai naudojant ir gana pelningi. Prieš pradèdamas naudoti pasirinkimo sandorius investuotojas turi suprasti ir išsianalizuoti rizikas, susijusias su prekyba šiomis finansinėmis priemonėmis. Šio straipsnio tikslas - išnagrinèti pagrindinius pasirinkimo sandorių rizikos ir jautrumo veiksnius bei jų reikšmę investuotojui. Suprasdamas ir mokèdamas ịvertinti pasirinkimo sandorių jautrumą ịvertinančias graikiškąsias raides investuotojas gali valdyti ne tik šių sandorių riziką, bet ir viso portfelio rizikingumą. Kiekviena graikiškoji raide įvertina skirtingus pasirinkimo sandorių jautrumo aspektus.
\end{abstract}

Reikšminiai žodžiai: pirkimo pasirinkimas, pardavimo pasirinkimas, kaina, vertė, galiojimo trukmè, sulygta kaina, graikiškosios raidès, kintamumas, rizika, jautrumas, delta, gama, teta. 


\section{Introduction}

It could be stated that options include some special features that exclude them from other derivative securities. Options as financial means can be used in many possible ways for creating various opportunities for attractive investment. Empirical studies presented in financial literature by foreign and Lithuanian authors (Avellaneda, Laurence 2000; Hull 2000; Friedentag 2000; Rutkauskas 1998; Kancerevycius 2006) illustrate that options incorporate an insurance element not available in any other security and therefore can be used by investors for creating return distributions unobtainable with the strategy of allocating funds between stock portfolios and fixed income securities. Options can be used for speculating on profit, earning income to enhance investment returns and protecting against a temporary decline in the value of stock or other commodity both financial and material.

Still, everyone using option contracts as a hedging mean must understand and evaluate the degree of risk they impose. Sometimes investors do not pay proper attention to the evaluation and management of risky options and their investment strategies, which is the main condition for the successful use of these derivative securities.

Due to the complex valuation of option contracts, the main scientific studies are devoted to analyse separate methods of option pricing (Hull 2000; Jarrow, Rudd 1983; Martin 2001; Kancerevyčius 2003; Gregoriou 2010; Amaro et al. 2009). A big part of authors (Hull 2000; Bodie, Merton 2000; Haugen 2001; Rutkauskas 1998) are interested in how to manage the risk of value changes in the underlying asset or how to protect against losses in stock or currency markets. Nevertheless, the main condition of the successful use of the analysed derivative securities is the understanding, evaluation and management of risky options. It is important to investors to compare the necessity and possible dangers of using options in order to choose a proper strategy and to manage risk related to this choice.

The purpose of this article is to analyse the main factors in option risk and sensitivity and to explain the possibilities of their management. The object of the article is option sensitivity factors as the measures of their riskiness.

In order to reach the purpose of the article, the following steps are going to be made:

1) to define the main concepts describing the features of options;

2) to analyse factors in option sensitivity and risk;

3) to determine the possibilities of managing factors in option risk.

An analytical systemic analysis of scientific literature and papers produced by foreign and Lithuanian scientists as well as comparative analysis and graphical modelling were used for investigation purposes.

\section{The Main Features of Option Contracts}

A review of financial literature allows making a conclusion that different authors (Hull 2000; Rutkauskas 1998; Kancerevycius 2006) give almost the same description of option contract emphasising the right to choose. An option is an instrument giving its owner the right but not obligation to buy or sell something at a price fixed in advance. Options are used on a wide range of products starting from raw materials and ending in financial assets, gold or real estate. The article mainly focuses on stock options because these instruments are widely traded as over the counter contracts and appear in exchanges.

Two types of stock options - calls and puts (Whaley 2006) are available. A call option gives the holder the right to buy a specified quantity of stock at the strike price on or before expiration date. The writer of the option, however, has the obligation to sell the underlying asset if the buyer of the call option decides on exercising his right to buy. A put option gives the holder the right to sell the specified quantity of the underlying stock at the strike price on or before expiration date. The writer of the put option has the obligation to buy the agreed stock at the strike price if the buyer decides on exercising his right to sell. The option holder is the person who buys the right conveyed by the option. The option writer or seller is obliged to perform according to the terms of the option. The strike price or exercise price is the one at which the option holder has the right either to purchase or sell the underlying asset (Whaley 2006).

Three different terms describing how an option is trading in relation to the price of the underlying asset can be defined. "At the money" means that the current market value of the underlying stock is the same as the exercise price of the option. The call option is supposed to be "in the money" if the current market value of the underlying stock is above the exercise of the option. In the case of the put option, the current market value should be below the exercise price of the option. If the exercise price is above the current market value in the case of the call option and below in the case of the put option, the option is said to be "out of the money". These options can be exercised only at a lost (Whaley 2006).

The style of an option refers to when that option is exercisable. According to Options Clearing Corporation (OCC), three different styles of options can be adopted: American style, European style and capped. An American style option may be exercised at any time prior to its expiration. A European style option may be exercised only during a specified period before the option expires. Usually such an option is exercised on its expiration day. Capped options are not traded in every exchange. Their trading conditions are individual depending on the exchange they are traded. A capped option will be automatically exercised prior to expiration if the option market on which the option is trading determines that the value of the agreed asset at a specified 
time on a trading day reached the cap price of the option (Cuthbertson, Nitzsche 2003).

The main types of risk associated with options are not new or some kind exotic. They are basically the same as those faced in traditional activities, for example price, credit, liquidity, interest rate risk, etc. These types of risk are the same for options on all types of underlying interests, but some are special and may apply only to options on particular types of the underlying asset. New types of options and new investment strategies, including these contracts, are especially risky because of their newness, complexity and the inexistence of usage experience.

The authors studying the risk of options and other derivative securities such as futures, forwards and swaps, distinguish different kinds of risk characteristic of option contracts.

Market and credit risk is pointed out as the main one by Minehan C. E., Simons K. (1995) and Remolona E. M., Bassett W., Geoum I. S. (1996). Besides these two types of risk mentioned by Kojima J. Ch. (1995), an emphasis on the third one, i.e. systemic risk, as the combination of market and credit risk (Kojima J. Ch., 1995; Mačerinskienè I., Melnikas N., Ragauskaitė V., 2001). Sill K. (1997) points out credit risk, pricing risk and liquidity risk.

According to Options Clearing Corporation (OCC), these types of risk are strategic, reputation, price, foreign exchange, liquidity, interest rate, credit, transaction and compliance (Comptroller's handbook, 1998). Becker B. and Mazur F. I. (1995) mark out market, credit, liquidity, legal and operational risk. Macey J. R. (1995) separates localised and systematic risk. Battaglia P. (1995) uses classification such as market risk, credit risk, operational risk, legal risk and system risk. A similar classification is used by Krawiec K. D. (1998) who mentions documentation risk, delivery/settlement/transaction risk, system and model risk and accounting/tax risk.

Some types of risk associated with options are the same found in more traditional lending and investment activities. However, because over the counter options are customized to meet the needs of a particular counterparty, these types of risk are often assembled in new and unexpected ways, sometimes leading to unforeseen losses (Krawiec 1998).

\section{Analysis of Option Sensitivity Factors}

The main factors in option sensitivity and risk are reflected in the Black - Scholes option pricing model. The Black - Scholes formula was the first widely used model for the option price of the underlying pricing (Hull 2000). These factors would be the price of the underlying asset, strike price, interest rate, etc. Thus, the conclusion that option contracts are especially sensitive to market changes could be made. The essence of the option-pricing problem is estimating price movement under the circumstances of uncertainty. In the case of option pricing, uncertainty is defined as the fact that we do not know what the price of the underlying instrument will be on the expiration date of the option.

It is not easy to determine the right price of option contract in practice. A big number of pricing models and programs were generated to solve this problem. The Black-Scholes model and the Cox, Ross and Rubinstein binomial models are the primary pricing models. The Black-Scholes model is used for calculating a theoretical price of the option (ignoring dividends paid during the life of the option) using the five key determinants of the price of the option (Hull 2000):

1) the current price of the underlying asset;

2) strike price;

3) time for expiration;

4) interest rates;

5) dividends expected during the life of the option;

6) the volatility of the underlying stock.

Stock price and strike price. The payoff from the call option will be the amount by which the stock price exceeds the strike price. Call options therefore become more valuable as the stock price increases and less valuable as the strike price increases. For the put option, the payoff on exercise is the amount by which the strike price exceeds the stock price. Thus, the put option becomes less valuable as the stock price increases and more valuable as the strike price increases.

Time for expiration. Both put and call American options become more valuable as time for expiration increases. European put and call options do not necessarily become more valuable as time for expiration increases. This is because it is not true that the owner of a long-life European option has all exercise opportunities open to the owner of a short-life European option.

Volatility. Volatility is an important component of a price of the option. The volatility of the stock price is a measure of how uncertain we are about future stock price movements. There are two kinds of volatility: historic and implied. Historic volatility is a measure of how much the underlying stock price has moved in the past. The higher is historic volatility, the more the stock price has changed over time. An investor can use historic volatility as an indication of how much the stock price may fluctuate in the future, but there is no guarantee that past performance will be repeated.

Implied volatility is the percentage of volatility that justifies the market price of the option. Investors may use implied volatility to predict how volatile the underlying asset will be, but like any prediction, it may or may not hold true (Byun et al. 2011).

Volatility is a key element in the time value portion of an option's premium. In general, the higher is volatility-either historic or implied-the higher is the option's premium will be.

As volatility increases, a chance that stock will act very well or poorly becomes higher. The value of both calls and puts therefore grows as volatility rises. 
Risk-free interest rate. The risk-free interest rate affects the price of an option in a less clear-cut way. Without additional assumptions, it is difficult to gauge the effect of increasing interest rates. Since they decrease the present value of the exercise price, there is a tendency for call values to increase and put values to reduce. It should be emphasised that these results assume that all variables remain fixed. In practice, when interest rates fall (rise), stock prices tend to rise (fall). The net effect of an interest rate change and the accompanying stock price change, and therefore may be different from the one given (Hull 2000; Jarow, Rudd 1983; Brenner, Subrahmanyam 1994).

Dividends. Dividends have the effect of reducing the stock price on ex-dividend date. The values of call options are negatively related to the size of any anticipated dividend, and the value of the put option is positively related to the size of any anticipated dividend.

Some assumptions were made to derive the BlackScholes model: there are no transaction costs, no dividends during the life of the option, no riskless arbitrage opportunities, security trading is continuous, the stock price follows the geometric Brownian process with mean and standard deviation constant and the risk-free rate of interest is constant and the same for all maturities.

Though the Black-Scholes model is derived for valuing European call and put options on non-dividend-paying stock, this model can be extended to deal with European call and put options on dividend-paying stocks, American options or the options having different underlying assets. For empirical analysis, stock paying dividends were chosen (Hull 2000):

$$
\begin{gathered}
c=S e^{-q(T-t)} N\left(d_{1}\right)-X e^{-r(T-t)} N\left(d_{2}\right), \\
p=X e^{-r(T-t)} N\left(-d_{2}\right)-S e^{-q(T-t)} N\left(-d_{1}\right), \\
d_{1}=\frac{\ln (S / X)+\left(r-q+\sigma^{2} / 2\right)(T-t)}{\sigma \sqrt{T-t}}, \\
d_{2}=d_{1}-\sigma \sqrt{T-t},
\end{gathered}
$$

where $\mathrm{c}$ - premium of the European call option;

$\mathrm{p}$ - premium of the European put option;

$\mathrm{S}$ - the price of the underlying stock;

$\mathrm{X}$ - exercise or strike price;

$\mathrm{T}-\mathrm{t}$ - time for maturity;

$r$ - risk free interest rate;

$\mathrm{q}$ - expected rate of dividends;

$\sigma$ - volatility of the stock price;

$\mathrm{N}_{1}, \mathrm{~N}_{2}$ - the cumulative normal distribution function.

Options are highly sensitive to the underlying asset price, time and volatility. The nature of this sensitivity to one input can change in essence as any of changes in the input (Bellalah 2010). The best way to understand the sensitivity of an option to each mentioned factor is to calculate the
Black - Scholes model derivatives known as Greek letters (delta, gamma, vega, lambda, theta, rho). These letters summarise a change in the option price resulting from a small change in the relevant input with all other inputs kept constant and show how sensitive and risky the option contract is.

Sensitivity to the price of the underlying asset: delta and gamma. The delta of an option is the sensitivity of the option to market movements. It provides an estimate of how much premium will change due to a change in the underlying price. The formula of calculating delta value is expressed in the form of (Martin 2001)

$$
\begin{gathered}
\text { Call delta }=\mathrm{N}\left(\mathrm{d}_{1}\right), \\
\text { Put delta }=N\left(d_{1}\right)-1 .
\end{gathered}
$$

If, for example, delta is $45.3 \%$, a 1 EUR change in the underlying price will cause the option premium to change by 45.3 cents. In the case of a call, the underlying price and premium move in the same direction, while for a put, there is negative relationship that a rise in the underlying price will result in a fall in the put premium. Delta is between 0 and +1 for calls and between 0 and -1 for puts.

Can three usual situations be concerned with delta (Hull 2000; Avellaneda, Laurence 2000):

- delta is equal to 1 (100\%). In such case, a change in the option value is the same as the underlying price change and is likely to be exercised;

- delta is equal to 0.5 (50\%). Each change in the underlying price will cause a half of a change in that price considering the option that is "at the money" and there is an equal chance that the option will be exercised or abandoned;

- delta is equal to $0(0 \%)$. The option is insensitive to changes in the underlying price and is unlikely to be exercised - it is deeply "out-of-the-money".

Bought calls and sold puts have positive deltas; bought puts and sold calls have negative deltas (Hull 2000; Avellaneda, Laurence 2000).

Delta represents the first derivative of the Black-Scholes model with respect to the price. If we plot the sensitivity of the option price to changes in the underlying price, delta is the tangent to this curve at the prevailing price, which is shown in Figure 1.

As shown in Fig. 1, the sensitivity graph of the option price is curved; the tangent becomes steeper as the price rises. This is a unique characteristic of options: delta can fall anywhere between zero and one, i.e. price sensitivity can vary from being insensitive to spot price movements to the other extreme of the spot price and the option price being perfectly correlated (Hull 2000; Avellaneda, Laurence 2000). This sensitivity and underlying asset price are related, as delta will vary by changes in the underlying asset price (see Fig. 2). 
Delta of call option
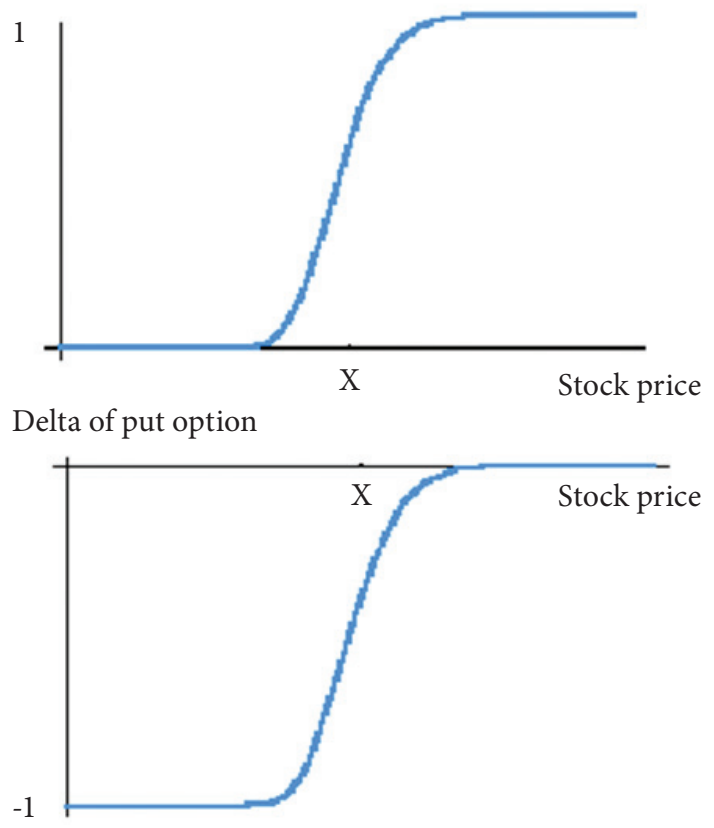

Fig. 1. Delta coefficient as the sensitivity of the option to the stock price (Hull 2000; Avellaneda, Laurence 2000)

This sensitivity of delta to the underlying asset price is known as gamma risk. Gamma is the second derivative of the Black-Scholes formula with respect to the underlying asset price and is calculated using the following rearrangement of the Black-Scholes formula (Hull 2000):

$$
\text { Gamma }=\frac{N^{\prime}\left(d_{1}\right)}{S_{0} \sigma \sqrt{T}},
$$

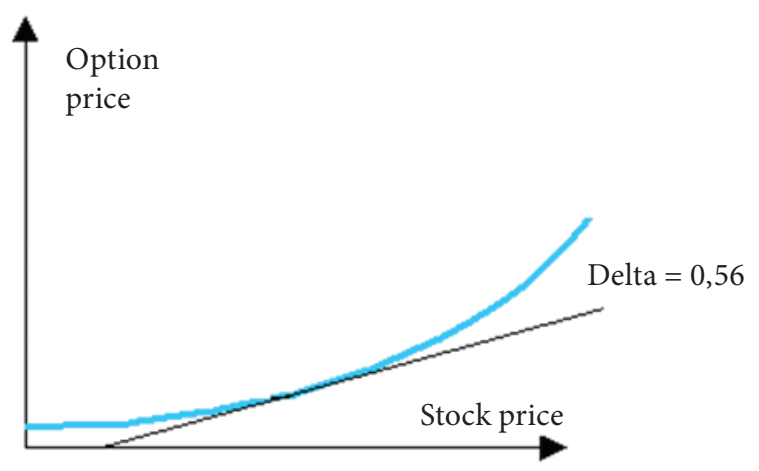

Fig. 2. Variation of delta with the stock price (Hull 2000)

If, for example, gamma has a value of 0.6 , a 1 EUR increase in the price of the underlying asset will increase the delta of the option by approximately 0.6 . Low gamma (for example, less than 1\%) indicates stable delta that only changes slowly in response to movements in the underlying price. A high gamma option has delta that is very sensitive to movements in the underlying price. High gamma is associated with "at-the money" options with only a short time for expiry. The movement of gamma depending on the stock price is shown in Fig. 3.

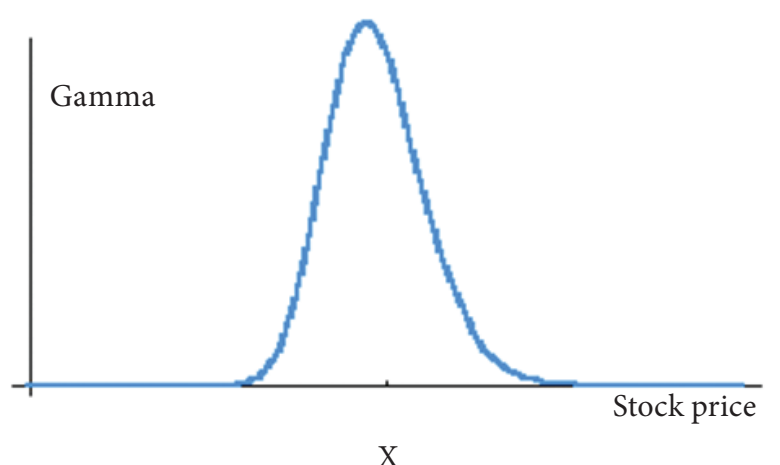

Fig. 3. Variation of gamma with the stock price (Hull 2000)

Bought options have positive gammas and sold options have negative gammas. In general, sold options having high gammas are viewed as undesirable because it is extremely uncertain as to whether or not they will be exercised and difficult to hedge (Hull 2000).

Sensitivity to time - Theta. One risk particular to options is time decay, because the value of an option diminishes as the expiration date approaches. For this reason, options are considered wasting assets, i.e. have no value after a certain date. An option's premium has two parts: an intrinsic value and time value. The intrinsic value is the amount by which the option is in-the-money. Time value is the difference between whatever the intrinsic value is and what the premium is. The longer is the amount of time for market conditions to work to your benefit, the greater is the time value (Amaro et al. 2009). Different time horizons will give a different range of outcomes, that is, the longer is the time period, the more chances of larger price movements from the current underlying asset price are in the desirable direction.

Passing time decreases the value of both calls and puts; this process is referred to as time decay that is not a linear process. The closer is the expiration date of the option, the more rapid is the loss of the option's time value (Hsuan-Ku Liu, Ming Long Liu 2009).

Theta is an indicator for option's sensitivity to time and measures the units of change in the option price for a 1-day decrease in days remaining to expiration.

The formula for calculating theta is as follows (Hull 2000):

$$
\begin{aligned}
& \text { Theta }_{\text {call }}=-\frac{S_{0} N^{\prime}\left(d_{1}\right) \sigma}{2 \sqrt{T}}-r X e^{-r T} N\left(d_{2}\right) \text { Theta }_{p u t}= \\
& -\frac{S_{0} N^{\prime}\left(d_{1}\right) \sigma}{2 \sqrt{T}}+r X e^{-r T} N\left(-d_{2}\right) .
\end{aligned}
$$

The variation of theta with the stock price is shown in Fig. 4. 


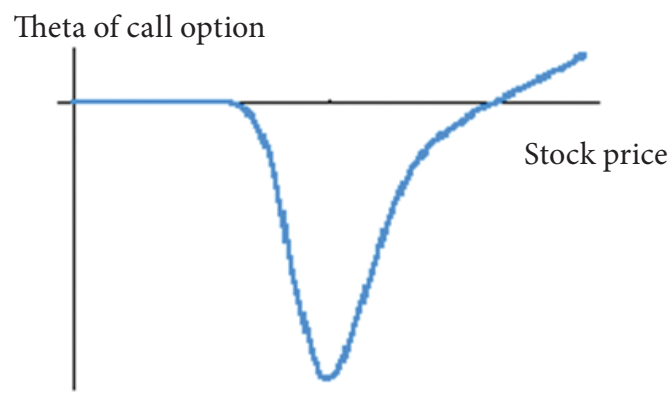

Theta of call option

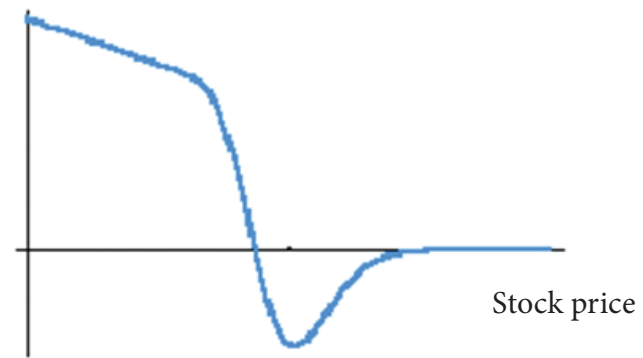

Fig. 4. Variation of theta with the stock price (Hull 2000)

If, for example, theta has a value of - 0.04, a 1 day decrease in time for expiration will decrease the price of the option by approximately $0.04 \mathrm{EUR}$. Theta is generally the largest for "at-the-money" options. "In-the-money" options typically have larger theta than "out-of-the-money".

Sensitivity to underlying asset volatility: vega. Volatility is a very important factor in deciding what kind of options to buy or sell. Volatility shows the range that the stock price has fluctuated in a certain period. There are two types of volatility - statistical and implied. Statistical volatility is a measure of actual asset price changes over a specific period of time. Implied volatility measures how much the investor expects asset price to move. The price of an option is linked to the expected future distribution of the underlying asset price. As expectations of volatility change, so will the option premium. The Greek letter used for describing the sensitivity of the option premium to volatility is vega.

The formula for calculating vega can be expressed as follows (Hull 2000):

$$
V e g a=S_{0} \sqrt{T} N^{\prime}\left(d_{1}\right) .
$$

"At-the-money" options have the greatest vega. The further an option goes "in-the-money" or "out-of-the-money", the smaller is the vega. As time passes, vega decreases. Time increases the effect of volatility changes. As a result, vega is greater for long-dated rather than for short dated options.

Bought options have positive vega (long volatility) and sold options have negative vega (short volatility). If the option has a vega of $+6,8657$, that implies that a $1 \%$ rise in volatility will increase the option premium by 6.87 cents.

Sensitivity to the interest rate: Rho. Options are sensitive to changes in interest rates, and the longer is time remaining to expiration, the greater is sensitivity. Changes in interest have a lesser effect on out-of-the-money options than at- or in-the-money options. The formulas for calculating rho are (Perilla, Oancea 2003)

$$
\begin{gathered}
r h o=X T e^{-r t} N\left(d_{2}\right), \\
r h o=-X T e^{-r t} N\left(-d_{2}\right) .
\end{gathered}
$$

Increasing interest rates will decrease put values and increase call values. Decreasing interest rates have the opposite effect. A change in the option value for a one percent change in the interest rate is indicated by rho. Certainly, the option premium tends to be substantially less sensitive to changes in the interest rate than to changes in the underlying price, volatility and time.

\section{Empirical Research on Delta Hedging}

If an investor hedges investment, he protects himself against losses, usually with another investment that requires additional capital. Considering available options, it is possible to hedge a long stock position by writing a call or purchasing a put on that stock. Hedging is often compared to buying insurance on investment, since you spend some money protecting yourself against the unexpected (Ostermark 2011).

The delta of an option is equivalent to the hedge ratio concept. Delta can be interpreted as the number of the units of the underlying asset equivalent to the position of the option. Thus, if delta is equal to $56.6 \%$, the investor should buy 566 units of the underlying asset in order to hedge his position. This creates a "delta neutral" position, as changes in the option premium will be offset by a change in the value of the hedged asset.

In order to analyze delta hedging as the mean of managing option sensitivity and risk, an empirical situation was imitated and simulated. The main conditions of analysis are presented in Table 1.

Table 1. Data used for simulating results

\begin{tabular}{l|l}
\hline Stock price & $\$ 10-\$ 150,00$ \\
\hline Annual Dividend Yield (D/P) & $.00 \%$ \\
\hline Exercise price & $\$ 100,00$ \\
\hline Risk Free Rate & $10.00 \%$ \\
\hline Time to expiration (years) & 1.00 \\
\hline Volatility (annualized) & $25.0 \%$ \\
\hline
\end{tabular}

After imitating the situation, the results of the main option sensitivity factors were acquainted (see Table 2). Data presented in Table 2 show how Greek letters are related to a growing price of stock.

In order to better understand the relationship between the stock price and option Greek letters, some results are presented in a graphical form (Fig. 5). 
Table 2. Relationship between stock price and option sensitivity measures

\begin{tabular}{c|c|c|c|c|c|c|c|c}
\hline $\begin{array}{c}\text { Stock } \\
\text { price }\end{array}$ & Call delta & Put delta & Call theta & Put theta & Call rho & Put rho & Gamma & Vega \\
\hline 10 & 0 & -0.95238 & 0 & 0 & 0 & 0 & 0 & 0 \\
\hline 60 & 0.039635 & -0.91275 & -0.7252 & 5.151355 & 2.157016 & -88.7521 & 0.00565 & 5.08512 \\
\hline 80 & 0.267099 & -0.68528 & -3.92349 & 1.023724 & 18.44066 & -72.4684 & 0.016042 & 25.66762 \\
\hline 90 & 0.434344 & -0.51804 & -5.45425 & -0.9717 & 32.66257 & -58.2465 & 0.016784 & 33.98744 \\
\hline 100 & 0.592505 & -0.35988 & -6.17743 & -2.15955 & 47.66839 & -43.2407 & 0.01448 & 36.19989 \\
\hline 105 & 0.660625 & -0.29176 & -6.21108 & -2.42554 & 54.64705 & -36.262 & 0.012733 & 35.09616 \\
\hline 110 & 0.71965 & -0.23273 & -6.06146 & -2.50825 & 60.98831 & -29.9208 & 0.010872 & 32.88766 \\
\hline 115 & 0.769414 & -0.18297 & -5.76939 & -2.44851 & 66.58302 & -24.3261 & 0.009051 & 29.92344 \\
\hline 120 & 0.810395 & -0.14199 & -5.3772 & -2.28866 & 71.39482 & -19.5143 & 0.007372 & 26.53812 \\
\hline 125 & 0.843465 & -0.10892 & -4.92338 & -2.06717 & 75.44279 & -15.4663 & 0.005892 & 23.01608 \\
\hline 130 & 0.869686 & -0.0827 & -4.4396 & -1.81573 & 78.78329 & -12.1258 & 0.004633 & 19.57543 \\
\hline 135 & 0.890161 & -0.06222 & -3.94982 & -1.55828 & 81.49412 & -9.41497 & 0.003592 & 16.36643 \\
\hline 140 & 0.90594 & -0.04644 & -3.47059 & -1.31138 & 83.66197 & -7.24712 & 0.002751 & 13.4791 \\
\hline 145 & 0.917961 & -0.03442 & -3.01216 & -1.08529 & 85.37352 & -5.53558 & 0.002084 & 10.95504 \\
\hline 150 & 0.927027 & -0.02535 & -2.57988 & -0.88534 & 86.7097 & -4.19939 & 0.001564 & 8.800223 \\
\hline
\end{tabular}

Using data presented in Table 2, the example of delta hedging was analyzed. Suppose that at the current stock price is $\$ 100$ and the option price is $\$ 11.58$. An investor has sold 20 option contracts (options to buy 2000 shares of stock). The delta of such option is 0.59 . The investor's position could be then hedged by buying $0.59 \times 2000=1180$ shares. The gain or loss on the option position would be offset by the loss or gain on the stock position.

If the stock price goes up by $\$ 1$, what produces a gain of $\$ 1180$ on the shares purchased, the option price will tend to go up by $0,59 \times \$ 1=\$ 0.59$ giving a loss of $\$ 1180$ on the option written. The opposite situation is in the case of a decreasing price of the share. If it goes down by $\$ 1$ giving the loss of $\$ 1180$ on the purchased shares, the position from the option will generate a gain of $\$ 1180$.

A portfolio is hedged when its position delta is equal to zero. The analyzed example shows that the investor loses $1180 \Delta \mathrm{S}$ on the short position when the stock price increases by $\Delta S$. The delta of the stock is equal to 1 and the long position in 1180 shares has the delta of +1180 . Therefore, the delta of the investor's overall position is equal to zero. The delta of the stock position offsets the delta of the option position called delta neutral. There are some investment strategies that are delta neutral and often make money while the market remains stable. Such strategies include straddles, strangles and butterflies.

The problem remains because delta changes and the investor's position remains delta hedged or delta neutral for only a relatively short period of time. Thus, the hedge has to be adjusted periodically. If the price of the analyzed stock increased from $\$ 100$ to $\$ 105$, delta changed from 0.59 to 0.66 . Is such a situation, extra $0.07 \times 2000=140$ shares have to be purchased to maintain the hedge.

In order to maintain the delta neutral position, the investor has to understand what causes price movements of the underlying asset, what factors affect changes in option prices and to manage the risks connected with the trade of option contracts.

\section{Conclusions}

The main distinguishing feature of the option contract is that his holder is provided a possibility of choice when using this contract. The writer of the option is in the opposite position and has the obligation to fulfil the will of the holder of the option.

The main types of risk related to options are not new. They are basically the same as those faced in traditional activities, for example price, credit, liquidity, interest rate risk, etc. The option risk can be divided into two groups: common risk and specific risk. The first group consists of market risk, liquidity risk, credit risk, legal risk and transactions risk and is general to mostly all traded securities.

Concluding the analysis of the main measures of option contracts, it may be agreed that risk measurement and control over these contracts are quite difficult constant processes. The most informative are delta, gamma and vega coefficients. Delta is the amount by which option changes are compared to those in the underlying asset. It is also useful in the form of a hedge ratio. Gamma measures the rate of changes in the delta coefficient. Vega shows how the investor's position is exposed to changes in volatility. Theta and rho give information about option sensitivity to time and changes in the risk free interest rate. 


\section{Call delta}

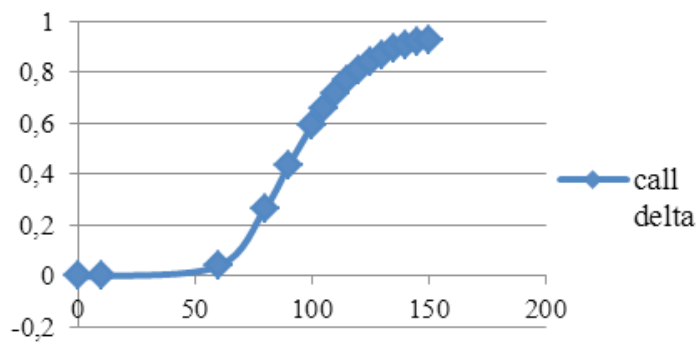

Put delta

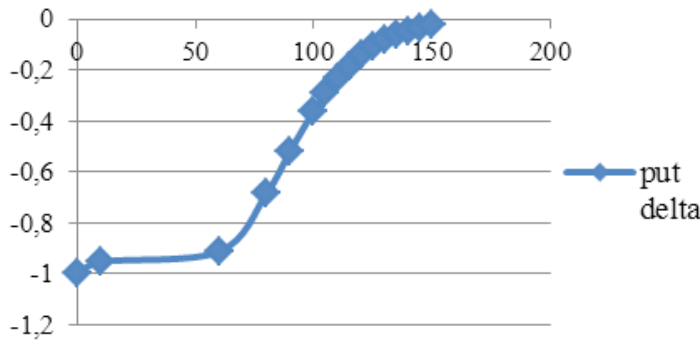

Gamma

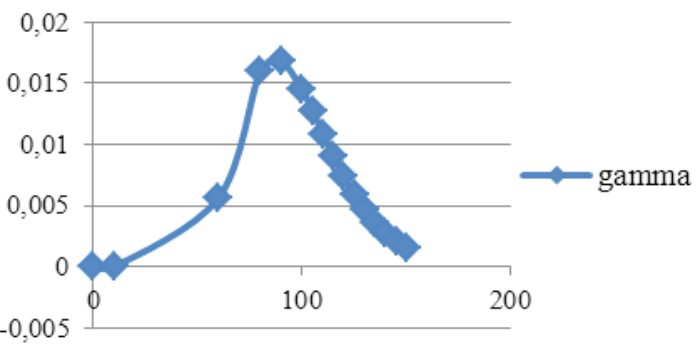

Vega

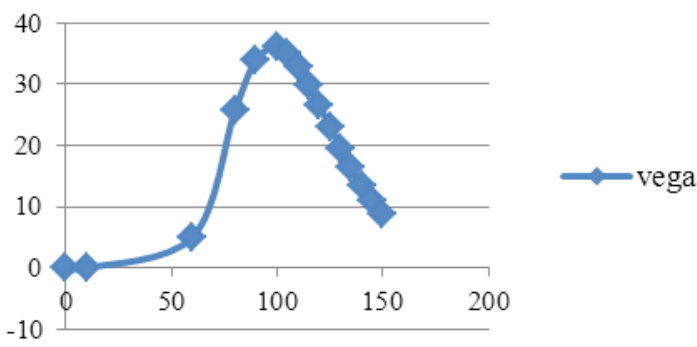

Fig. 5. Graphical presentation of some calculated option Greeks

All these measures are interdependent and change constantly. They enable the measurement of how much the risk portfolio is exposed to and where that risk lies.

The principal problem is the non-existence of constant relationships between the prices of the option and underlying asset. Besides that, the value of the option contract is influenced by time decay, uncertainty about the underlying asset price in the future, risk free interest rate changes and other factors. The investor must observe and estimate all above mentioned factors and hedge them according to the counted delta. The manager of the portfolio has to decide on how frequently to overlook the structure of the portfolio and adjust it according to changes in the market.

\section{References}

Amaro de Matos, J.; Dila o, R.; Ferreira, B. 2009. On the value of European options on a stock paying a discrete dividend, Journal of Modelling in Management 4(3): 235-248. http://dx.doi.org/10.1108/17465660911006468

Avellaneda, M.; Laurence, P. 2000. Quantitative modeling of derivative securities. From theory to practice. Chapman and hall/CRC. $322 \mathrm{p}$.

Battaglia, P. 1995. Derivatives, Internal Auditor 52: 50-57.

Becker, B.; Mazur, F. I. 1995. Risk management of financial derivative products: who's responsible for what?, Journal of Corporation Law 21: 177-206.

Bellalah, M. 2010. Derivatives, Risk Management \& Value. World Scientific Publishing Co.: eBook. 996 p. Available from Internet: eBook Academic Collection <http://web. ebscohost.com>.

Bodie, Z.; Merton, R. C. 2000. Finance. New Jersey: Prentice hall. 480 p.

Brenner, M.; Subrahmanyam, M. G. 1994. A simple approach to option valuation and hedging in the Black-Scholes model, Financial Analysis Journal 50(2): 25-28. http://dx.doi.org/10.2469/faj.v50.n2.25

Byun, S. J.; Rhee, D. W.; Kim, S. 2011. Intraday volatility forecasting from implied volatility, International Journal of Managerial Finance 7(1): 83-100. http://dx.doi.org/10.1108/17439131111109017

Cuthbertson, K.; Nitzsche, D. 2003. Financial engineering derivatives and risk management. John Wiley and Sons, LTD. 776 p.

Friedentag, H. C. 2000. Stocks for options trading: low-risk, low-stress strategies for selling stock options profitably. USA: CRC Press LLC. 230 p.

Gregoriou, A. 2010. Modeling the non-linear behavior of option price deviations from the Black Scholes model, Journal of Economic Studies 37(1): 26-35. http://dx.doi.org/10.1108/01443581011012243

Haugen, R. A. 2001. Modern investment theory. New Jersey: Prentice hall, $5^{\text {th }}$ edition. $656 \mathrm{p}$.

Hsuan-Ku Liu; Ming Long Liu. 2009. Pricing and hedging American options in incomplete markets, Journal of Modelling in Management 4(1): 72-82. http://dx.doi.org/10.1108/17465660910943766

Hull, J. 2000. Options, Futures, and Other Derivative Securities. Forth Edition. New Jersey: Prentice hall. 698 p.

Jarrow, R. A.; Rudd, A. 1983. Option pricing. USA: Richard D. Irwin, INC. 235 p.

Kancerevyčius, G. 2006. Finansai ir investicijos. Kaunas: Smaltija. 864 p. (in Lithuanian).

Kojima, J. Ch. 1999. Product-based solutions to financial innovation: the promise and danger of applying the federal 
securities law to OTC derivatives, American Business Law Journal 33(2): 259-339.

http://dx.doi.org/10.1111/j.1744-1714.1995.tb00893.x

Krawiec, K. D. 1998. More than just "new financial bingo": A risk-based approach to understanding derivatives, Journal of Corporation Law 23: 1-63.

Mačerinskienè, I.; Melnikas, N.; Ragauskaite, V. 2001. The risk of derivative financial means and its management, Social Sciences 5(31): 18-28 (in Lithuanian).

Macey, J. R. 1995. Derivative instruments: lessons for the regulatory state, The Journal of Corporation Law Fall: 69-93.

Martin, J. S. 2001. Applied math for derivatives: a non-quant guide to the valuation and modeling of financial derivatives. Asia: John Wiley \& Sons. 447 p.

Minehan, C. E.; Simons, K. 1995. Managing risk in the '90s: what should you be asking about derivatives?, New England Economic Review Sep/Oct: 3-26.

Ostermark, R. 2011. Hedging with options and cardinality constraints in multi-period portfolio management systems, Kybernetes 40(5/6): 703-718.

http://dx.doi.org/10.1108/03684921111142269
Perilla, A.; Oancea, D. 2003. Pricing and hedging exotic options with Monte Carlo simulations. University of Lausanne. Master of science in banking and finance. $81 \mathrm{p}$.

Remolona, E. M.; Bassett, W.; Geoum, I. S. 1996. Risk management by structured derivative product companies, FRBNY Economic Policy Review 6(1): 17-38.

Risk Management of Financial Derivatives. Comptroller's Handbook (Comptroller of the Currency Administrator of National Banks) [online], [cited on 24 January 2013]. Available from Internet: http://www.occ.gov/publications/ publications-by-type/comptrollers-handbook/deriv.pdf

Rutkauskas, A. V. 1998. Financial markets and institutions. Vilnius: Technica. 420 p.

Sill, K. 1997. The economic benefits and risks of derivative securities, Business Review Jan/Feb: 15-27.

Whaley, R. E. 2006. Derivatives. Markets, valuation and risk management. New Jersey: John Wiley \& Sons. 930 p.

Raimonda MARTINKUTE-KAULIENE is a lecturer at the Department of Finance Engineering at Vilnius Gediminas Technical University. Defended the doctoral dissertation Selection and Management of Investment Strategies Portfolio in 2006 and was awarded the degree of Doctor in Social Sciences (Economics). Research of interest includes risk management and derivative securities. 